\title{
Isän ja emän perimän vaikutus kanan tuotanto-ominaisuuksiin
}

\author{
Maria. Tuiskula-Haavisto ${ }^{l}$, Dirk-Jan. de Koning ${ }^{2}$, Mervi. Honkatukia ${ }^{l}$, Nina Schulman ${ }^{l}$, Asko. \\ Mäki-Tanilal, and Johanna. Vilkki ${ }^{l}$ \\ ${ }^{1}$ Kotieläintuotannon tutkimus, Eläinjalostus, MTT Maa- ja elintarviketalouden tutkimus, 31600 Jo- \\ kioinen,etunimi.sukunimi@mtt.fi \\ ${ }^{2}$ Roslin Institute (Edinburgh), Roslin,EH25 9PS, U.K., DJ.deKoning@BBSRC.AC.UK
}

\section{Tiivistelmä}

Vastavuoroisesti (resiprookkisesti) risteytettyjen linjojen jälkeläisissä on eroja tuotantoominaisuuksissa, sukukypsyysiässä, kananmunanlaadussa ja elävyydessä. Siipikarjan jalostus perustuu osittain näiden erojen hyväksikäyttöön. Tällä hetkellä kaikki tuotantopolven munijakanat ovat linjaristeytyksiä eli hybridejä joissa emo ja isälinjat on valittu niiden resiprookkisten jälkeläisryhmien tuotannon perusteella. Vastavuoroisesti risteytettyjen linjojen jälkeläisten erilaisuuden on aiemmin oletettu johtuvan sukupuolikromosomeista tai maternaalisista vaikutuksista. Vaihtoehtoinen selitys voisi olla parent-of-origin vaikutus, missä geenin vaikutus on riippuvainen siitä kummalta vanhemmalta se on peritty. Resiprookkisten erojen selvittämiseksi tutkimme mahdollisia parent-of-origin vaikutuksia munijakanojen linjaristeytystutkimuksessa. Kaksi kananmunanlaadun suhteen erilaista munijakanalinjaa risteytettiin vastavuoroisesti, $\mathrm{F}_{2}$ sukupolvessa oli $305 \mathrm{kanaa}$. Sukupolvien $F_{1}$ ja $F_{2}$ kanat olivat tuotannontarkkailussa koko munintakauden (elinviikot 18-60). Resiprookkisia eroja havaittiin $F_{1}$ sukupolvessa sukukypsyysiässä, munamäärässä, munanpainossa, rehunkäyttökyvyssä, päiväsyönnissä ja valkuaisen laadussa.

$F_{2}$ sukupolven eläinten DNA:sta on analysoitu 92 mikrosatelliittimerkkiä 13 autosomista. Tutkimuksessa käytettiin tilasto-ohjelmaa, joka laski joko isältä tai emältä saadun alleelin vaikutuksen tuotanto-ominaisuuksiin. Löydettiin seitsemän aluetta, jotka vaikuttavat sukukypsyysikään, munan painoon, kanan painoon, päiväsyöntiin ja kananmunanvalkuaisen laatuun. Kahdessa alueessa tietty alleeli vaikuttaa vain isältä perittynä ja muissa äidiltä saatu alleeli. Kukin alue selittää noin 3-5 \% fenotyyppisestä vaihtelusta. Lisäanalyyseillä todettiin etteivät tulokset johdu emon mitokondrio DNA:sta (maternaalinen vaikutus) eivätkä ainoastaan muutamasta eläimestä. Tutkimuksemme on ensimmäinen, jossa on matemaattisilla menetelmillä osoitettu, että parent-of-origin vaikutus voi olla siipikarjan tuotanto-ominaisuuksissa havaittavien resiprookkisten erojen syy. Muissa tutkimuksissa on löydetty vastaavia alueita jotka vaikuttavat $\mathrm{mm}$. immuunivasteeseen ja kortisoni tasoon veressä. Nisäkkäillä vastaavaa ilmiötä kutsutaan geenien leimautumiseksi riippuen siitä kummalta vanhemmalta se on saatu (genomic imprinting). Nisäkkäillä nämä geenit vaikuttavat esim. sikiön kasvuun ja kehitykseen. Kanalla ilmiön taustan selvittämiseen tarvitaan lisätutkimuksia geenitasolla, jossa verrataan eri vanhemmalta perittyjen geenimuotojen ilmenemiseroja.

Avainsanat: siipikarja, resiprookkiset erot, jalostus 


\section{Johdanto}

Intensiivinen siipikarjanjalostus alkoi 1940-luvulla. Jalostus perustui erikoistuneiden osittain sisäsiitettyjen linjojen jalostukseen ja risteytykseen. Linjat on valittu erilaisten ominaisuuksien perusteella. Tuotantoeläimet ovat linjaristeytyksiä, hybridejä, joissa yhdistyvät eri ominaisuudet ja hyödynnetään heteroosia. Vastavuoroisesti tehdyt risteytykset tuottavat jälkeläisiä joiden tuotantoominaisuudet ovat erilaiset. Tällaisia eroja on löydetty kananmunatuotannossa, sukukypsyysiässä, kananmunanlaadussa ja elävyydessä (Fairfull et al., 1983). Nämä erot vaihtelevat suuresti eri linjojen välillä, eikä eroja voida etukäteen ennustaa, mikä vaikeuttaa risteytysten suunnittelua. Erojen on arveltu johtuvan sukupuolikromosomeista tai maternaalisesta vaikutuksesta (Fairfull, 1990). Vaihtoehtoinen selitys voisi olla parent-of-origin vaikutus, missä geenin vaikutus on riippuvainen siitä kummalta vanhemmalta se on peritty. Tällaiset vaikutukset johtuvat usein epigeneettisestä leimautumisesta, mikä vaikuttaa moniin geeneihin nisäkkäillä myös ihmisellä (Morison and Reeve, 1998). Kotieläimillä on löydetty viitteitä parent-of-origin vaikutuksesta geeneissä, jotka vaikuttavat tärkeisiin tuotanto-ominaisuuksiin lampailla (Charlier et al., 2001) ja sioilla (de Koning et al., 2000).

Tässä tutkimuksessa selvitettiin parent-of-origin vaikutusta munijakanaristeytys populaatiossa (Tuiskula-Haavisto et al., 2004). Vaikutusten löytyminen herättäisi kysymyksen onko syy samankaltainen kuin nisäkkäillä. Tällä hetkellä otaksutaan että parent-of-origin vaikutuksia esiintyy ainoastaan nisäkkäillä.

\section{Aineisto ja menetelmät}

Kartoituspopulaatio on muodostettu risteyttämällä kaksi munijakanalinjaa Rhode Island Red (RIR) ja Valkoinen Leghorn (WL). Linjat eroavat kananmunanlaadun suhteen toisistaan. Linjat risteytettiin resiprookkisesti. Sukupolvien $F_{1}$ ja $F_{2}$ kanat olivat tuotannontarkkailussa koko munintakauden (elinviikot 18-60). Tuotannontarkkailussa mitattiin munamäärä ja munanpaino, rehunkulutus, kananpaino ja kananmunanlaatu alku- (elinviikot18-40) ja loppumunintakaudella (elinviikot 41-60) (Tuiskula-Haavisto et al., 2002). Haudontaerä vaikutti lähes kaikkiin ominaisuuksiin ja sen vaikutus korjattiin tilasto-ohjelmalla (SAS Proc GLM). Resiprookkiset ja puhtaiden linjojen väliset erot laskettiin LS analyysillä (SAS Proc GLM).

Käytetyt heterotsygoottiset linjat mahdollistavat $F_{2}$ sukupolven eläinten alleelien periytymisen seuraamisen edelliseen sukupolveen. Tilastollisen menetelmän avulla laskettiin erikseen isältä ja emältä perityn RIR ja WL alleelien eron vaikutusta tutkittuihin ominaisuuksiin (de Koning et al., 2000;Knott et al., 1998). Koska tähän asti on resiprookkisten erojen oletettu johtuvan sukupuolikromosomeista tai maternaalisista vaikutuksista, lisäanalyyseillä selvitettiin mahdollinen Zkromosomin vaikutus ottamalla se co-faktoriksi. Maternaalivaikutus testattiin lisäämällä isoäidin vaikutus tilastolliseen malliin Proc GLM SAS ohjelmassa. Vaikutusten esiintyminen koko populaatiossa varmistettiin poistamalla vuorotellen osa jälkeläisistä analyysistä.

\section{Tulokset}

Resiprookkisia eroja havaittiin $\mathrm{F}_{1}$ sukupolvessa sukukypsyysiässä, munamäärässä, munanpainossa, rehunkäyttökyvyssä, päiväsyönnissä ja valkuaisen laadussa (Taulukko 1). Analyyseissä löytyi seitsemän aluetta (Kuva 1), jotka vaikuttavat sukukypsyysikään, munan painoon, kanan painoon, päiväsyöntiin ja kananmunanvalkuaisen laatuun, joissa RIR-alleelin vaikutus ilmenivain joko isältä tai emältä perittynä. Kromosomista 1 näitä alueita löytyi neljä: kananpaino, päiväsyönti, sukukypsyysikä ja valkuaisen laatu. Sukukypsyysikään vaikuttaa isältä saatu RIR alleeli alentamalla kahdella päivällä sukukypsyysikää. Muihin ominaisuuksiin vaikuttaa emolta saatu RIR alleeli niin että jälkeläinen syö vähemmän, painaa vähemmän ja munii vähemmän laadultaan parempia kananmunia. Kromosomissa 3 olevassa alueessa vaikuttaa isältä saatu RIR alleeli lisäämällä munanpainoa. Kromosomeissa 9 isältä saatu RIR alleelin vähensi päiväsyöntiä ja kromosomissa 11 emonta saatu RIR alleeli vähensi munatuotosta. Lisäanalyyseillä todettiin etteivät tulokset johdu emon mitokondrio DNA:sta (maternaalinen vaikutus). Z-kromosomilla ei myöskään ollut vaikutusta tuloksiin. Osa-populaatio analyysit osoittivat että tulokset eivät johdu ainoastaan muutamasta eläimestä. Taulukko 1. Least square means of performance and standard errors (in parentheses) for pure lines and crossbreeds. 


\begin{tabular}{|c|c|c|c|c|c|}
\hline Trait & Acronym & RIR & WL & $\mathbf{R I R} \hat{o} \mathbf{x} \mathbf{W L}+$ & WL $\widehat{\sigma} \mathbf{x} \mathbf{R I R}+$ \\
\hline Number of animals & & 128 q & 500 q & 93 9 & 63 우 \\
\hline Age at first egg (days) & AFE & $141,3^{\mathrm{a}}(0,8)$ & $135,6^{\mathrm{b}}(0,4)$ & $138,1^{\mathrm{c}}(0,9)$ & $130,4^{\mathrm{d}}(1,3)$ \\
\hline Body weight at $40 \mathrm{wk}(\mathrm{g})$ & BW40 & $2153^{\mathrm{a}}(16,1)$ & $1468^{\mathrm{b}}(8,0)$ & $1837^{\mathrm{c}}(18,6)$ & $1823^{\mathrm{c}}(23,9)$ \\
\hline Egg weight $18-40$ wk (g) & EWa & $56,4^{\mathrm{a}}(0,3)$ & $57,4^{\mathrm{b}}(0,2)$ & $58,1^{\mathrm{b}}(0,4)$ & $56,1^{\mathrm{a}}(0,5)$ \\
\hline Egg weight $40-60$ wk (g) & $\mathrm{EWb}$ & $61,5^{\mathrm{a}}(3,7)$ & $63,9^{\mathrm{b}}(1,8)$ & $64,3^{\mathrm{b}}(4,3)$ & $62,6^{\mathrm{a}}(5,5)$ \\
\hline Number of eggs $18-40 \mathrm{wk}$ & $\mathrm{ENa}$ & $140^{\mathrm{a}}(1,6)$ & $139^{\mathrm{a}}(0,8)$ & $136^{\mathrm{a}}(1,8)$ & $148^{\mathrm{b}}(2,3)$ \\
\hline Number of eggs $40-60 \mathrm{wk}$ & $\mathrm{ENb}$ & $95^{\mathrm{a}, \mathrm{b}}(1,8)$ & $96^{\mathrm{a}}(0,9)$ & $91^{\mathrm{b}}(2,1)$ & $100^{\mathrm{a}}(2,7)$ \\
\hline Feed intake per day $(\mathrm{g})$ & FI40 & $137,8^{\mathrm{a}}(1,1)$ & $112,4^{\mathrm{b}}(0,6)$ & $131,5^{\mathrm{c}}(1,3)$ & $125,4^{\mathrm{d}}(1,7)$ \\
\hline $\mathrm{Kg}$ feed/ kg eggs & FE40 & $2,70^{\mathrm{a}}(3,0)$ & $2,23^{\mathrm{b}}(1,5)$ & $2,64^{\mathrm{a}}(3,5)$ & $2,40^{\mathrm{c}}(4,5)$ \\
\hline Haugh 40 wk (HU) & HU40 & $75,2^{\mathrm{a}}(0,5)$ & $87,1^{\mathrm{b}}(0,2)$ & $80,3^{\mathrm{c}}(0,6)$ & $75,8^{\mathrm{a}}(0,7)$ \\
\hline Haugh 60 wk (HU) & HU60 & $66,0^{\mathrm{a}}(0,8)$ & $82,0^{\mathrm{b}}(0,3)$ & $71,5^{\mathrm{c}}(0,9)$ & $67,8^{\mathrm{a}}(1,1)$ \\
\hline Specific gravity $40 \mathrm{wk}$ & SG40 & $1081,8^{\mathrm{a}}(0,4)$ & $1080,7^{\mathrm{b}}(0,2)$ & $1082^{\mathrm{a}}(0,5)$ & $1082,5^{\mathrm{a}}(0,7)$ \\
\hline Specific gravity $60 \mathrm{wk}$ & SG60 & $1080,8^{\mathrm{a}}(0,7)$ & $1077,2^{\mathrm{b}}(0,3)$ & $1081,7^{\mathrm{a}}(0,7)$ & $1080,9^{\mathrm{a}}(1,0)$ \\
\hline Eggshell strength $40 \mathrm{wk} \mathrm{kp}$ ) & ES40 & $3,4^{\mathrm{a}}(0,4)$ & $3,4^{\mathrm{a}}(0,2)$ & $3,6^{\mathrm{b}}(0,5)$ & $3,6^{\mathrm{b}}(0,7)$ \\
\hline Eggshell strength $60 \mathrm{wk}(\mathrm{kp})$ & ES60 & $3,3^{\mathrm{a}}(0,06)$ & $3,1^{\mathrm{b}}(0,03)$ & $3,5^{\mathrm{a}}(0,07)$ & $3,6^{\mathrm{a}}(0,09)$ \\
\hline
\end{tabular}

Columns with different superscripts are significantly different from each other. 
GGA1

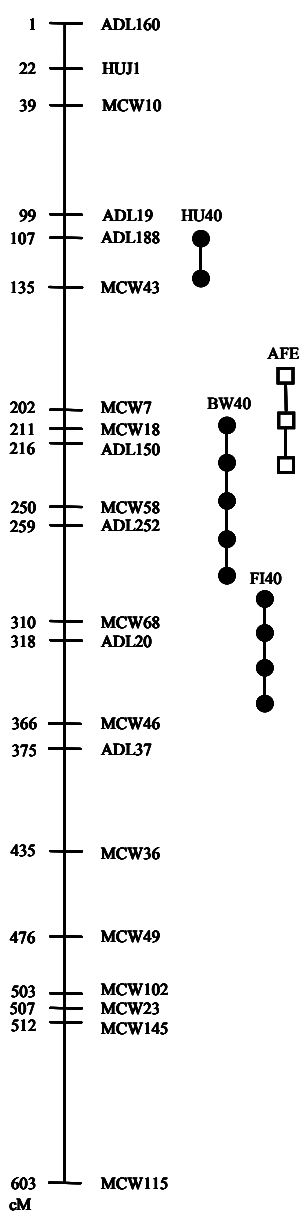

GGA3

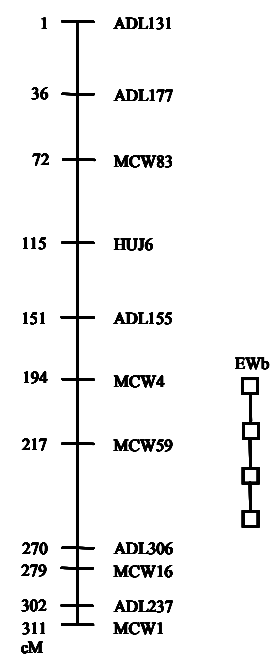

Kuva 1. Autosomal linkage groups showing uni-parentally expressed QTL affecting production and egg quality traits with $90 \%$ confidence intervals for paternally (line with open squares) or maternally (line with filled circles) expressed QTL. HU40 = Haugh unit at $40 \mathrm{wk}$ of age, AFE = age at first egg, BW40 = bodyweight at $40 \mathrm{wk}$ of age, $\mathrm{EWb}=$ average egg weight $41-60 \mathrm{wk}$ of age, $\mathrm{ENa}=$ total number of eggs at 18-40 wk of age, FI40 = feed intake per day $37-40 \mathrm{wk}$ of age.

\section{Johtopäätökset}

Tutkimuksessa löydettiin kromosomialueita joissa on parent-of-origin vaikutus seuraaviin ominaisuuksiin; sukukypsyysikä, munanpaino, munamäärä, päiväsyönti, kananpaino ja kananmunanlaatu. Nämä ominaisuudet ovat tärkeitä tuotanto-ominaisuuksia siipikarjanjalostuksessa ja resiprookkisia eroja on löydetty näihin ominaisuuksiin. Tässä tutkimuksessa löydettiin resiprookkisia eroja näissä ominaisuuksissa paitsi kananpainossa. Lisätutkimukset vahvistivat tutkimustulokset.

Muissa tutkimuksissa on löydetty linnuilla vastaavia alueita jotka vaikuttavat $\mathrm{mm}$. immuunivasteeseen ja veren kortisonitasoon. Nisäkkäillä vastaavaa ilmiötä kutsutaan geenien leimautumiseksi. Yleensä leimautuneet geenit nisäkkäillä esiintyvät ryhmissä ja vaikuttavat sikiöajan kasvuun. Tässä tutkimuksessa löytyneet 1 kromosomin alueet ovat keskittyneet samalle alueelle ja vaikuttavat myös kasvu-ominaisuuksiin.

Ilmiön katsotaan kehittyneen evoluution aikana vasta nisäkkäillä. Kuitenkin uudet bioinformatiikan työkalut antavat mahdollisuuden verrata eri eläinryhmien sekvenssitietokantoja. Tietokantaanalyysit, jossa verrattiin hiiren, ihmisen ja kanan sekvenssitietokantoja niistä geeneistä joiden tiedetään olevan leimautuneita ihmisellä, tukevat sitä olettamusta että nisäkkäiden geenien leimautuminen kehittyi "esi- leimautuneista" kromosomialueista ennen nisäkkäiden kehittymistä (Dunzinger et al., 2005). Ilmiön syyn tarkemmaksi selvittämiseksi linnuilla tarvitaan lisätutkimuksia geenitasolla, jossa verrataan eri vanhemmalta perittyjen geenimuotojen ilmenemiseroja. 


\section{Kirjallisuus}

Charlier, C., Segers, K., Karim, L., Shay, T., Gyapay, G., Cockett, N., and Georges, M. (2001). The callipyge mutation enhances the expression of coregulated imprinted genes in cis without affecting their imprinting status. Nat Genet 27:367-369.

de Koning, D. J., Rattink, A. P., Harlizius, B., van Arendonk, J. A., Brascamp, E. W., and Groenen, M. A. (2000). Genome-wide scan for body composition in pigs reveals important role of imprinting. Proc Natl Acad Sci U S A 97:7947-7950.

Dunzinger, U., Nanda, I., Schmid, M., Haaf, T., and Zechner, U. (2005). Chicken orthologues of mammalian imprinted genes are clustered on macrochromosomes and replicate asynchronously. Trends Genet 21:488-492.

Fairfull, R. W. (1990). Heterosis. In "Poultry Breeding and Genetics" (R. D. Crawford, Ed.), pp. 913-933, Elseveier science publishers b.v..

Fairfull, R. W., Gowe, R. S., and Emsley, J. A. (1983). Diallel cross of six long-term selected leghorn strains with emphasis on heterosis and reciprocal effects. Br Poult Sci 24 :133-158.

Knott, S. A., Marklund, L., Haley, C. S., Andersson, K., William, D., Ellegren, H., Fredholm, M., Hansson, I., Hoyheim, B., Lundström, K., Moller, M., and Andersson, L. (1998). Multiple Marker Mapping Of Quantitative Trait Loci in a cross Between Outbred Wild Boar and large White Pigs. Genetics 149:10691080 .

Morison, I. M. and Reeve, A. E. (1998). A catalogue of imprinted genes and parent-of-origin effects in humans and animals. Hum Mol Genet 7:1599-1609.

Tuiskula-Haavisto, M., de Koning, D. J., Honkatukia, M., Schulman, N. F., Maki-Tanila, A., and Vilkki, J. (2004). Quantitative trait loci with parent-of-origin effects in chicken. Genet Res 84:57-66.

Tuiskula-Haavisto, M., Honkatukia, M., Vilkki, J., de Koning, D. J., Schulman, N., and Mäki-Tanila, A. (2002). Quantitative trait loci in egg layers. Poult Sci 81:919-927. 